\title{
ИССЛЕДОВАНИЕ ПАМЯТНИКОВ ГУННСКОГО ВРЕМЕНИ В АКТЮБИНСКОЙ ОБЛАСТИ в 2018 г. (предварительное сообщение)
}

\author{
(C) 2018 г. А.А. Бисембаев, А.И. Хаванский, М.Н. Дуйсенгали, \\ А.М. Мамедов, Н.М. Баиров, В.А. Амелин
}

В статье изложены результаты раскопок памятников гуннского времени (Уилский p-н, Актюбинская обл.), а также результаты исследования разрушенного погребения у г. Актобе. В объекте № 15 (склепообразном «святилище») могильника Акбулак II было исследовано погребение воина с железным мечом без перекрестья, бронзовым уздечным набором и фибулой. В объекте 27 (гантелевидный курган) могильника Акбулак III выявлено погребение 1 в яме с подбоем. Погребение содержало останки погребенного с большим количеством украшений. Также в погребении находился бронзовый сосуд с носиком, поддоном и зооморфной ручкой. В разрушенном погребении у г. Актобе были обнаружены золотые вещи, выполненные в гуннском полихромном стиле, серебряная поясная пряжка. В целом получена представительная коллекция артефактов по вооружению, украшениям, конскому снаряжению и бытовым предметам. Исследованные комплексы укладываются в период второй половины II в. н.э. - IV в. н.э.

Ключевые слова: археология, Западный Казахстан, гунны, погребальный обряд, гуннский полихромный стиль

Гунно-сарматский период, или эпоха Великого переселения народов, представляет собой яркий отрезок истории. Он имеет широкий территориальный охват (от границ Китая до Испании) и эпохальный результат падение Западной Римской империи. Это время привлекает внимание исследователей по всему миру. В статье даются предварительные результаты полевых исследования памятников гуннского времени в Актюбинской области.

Данные полевые исследования являются логическим продолжением проекта «Пространственный анализ и архитектоника памятников гунносарматского периода Актюбинской области (II-IV вв. н.э.)». Первым этапом было проведение дешифровки космических снимков в программе SASPlanet. Положительной чертой данной программы является ее общедоступность, набор карт различного масштаба, а главное - спутниковых снимков высокого разрешения. В рамках камерального этапа было проведено детальное изучение космических снимков Уилского и Хобдинского районов с предварительным разделением их на условные участкиполигоны. 
После анализа космических снимков было проведено натурное обследование выявленных объектов. Обследование состояло из осмотра территории памятника, сбора подъемного материала, определение GPSкоординат объектов, описание памятника и проведение тахеометрической съемки. Сопоставление результатов анализа космоснимков и натурного обследования показало, что некоторые детали объектов фиксируются только на космоснимках. Так, кольцевой ров, особенно мелкий, может практически не фиксироваться визуально, между тем на материале космического наблюдения рвы четко выделяются от окружающего рельефа более темным оттенком. Также валы и рвы подквадратных склеповых объектов («святилищ») могут выделяться на окружающей местности на 10 см и слабо читаться в рельефе. Однако на космических снимках они распознаются за счет разницы цветов.

По итогам полевых работ результаты анализа космических снимков получили практически 100\% подтверждение на местности. Была проведена детальная тахеометрическая съемка на 10 погребальнопоминальных полях (могильниках) и отдельных объектах. Общее число выявленных объектов (курганов, гантелевидных курганов, склепообразных «святилищ») превысило 250 [Дуйсенгали и др., 2018, с. 237-241].

Летом 2018 г. для полевых стационарных исследований были выбраны могильники Акбулак I-III, расположенные в Уилском районе Актюбинской области. Материалы интересующего нас времени были исследованы в могильниках Акбулак II, III. Для изучения были выбраны объекты разных типов.

В объекте № 15 (склепообразном «святилище») могильника Акбулак II было исследовано погребе- ние 1 (рис. 1). Погребение совершено в грунтовой яме. Верхний контур подовальный, размеры 2,6×0,7 м, ко дну яма приобретает прямоугольную форму и размеры $2,2 \times 0,7$ м. Яма ориентирована по линии С3-ЮВ. Глубина ямы составляла 1,65 м от уровня материка. В заполнении ямы найдены отдельные бронзовые бляшки и фрагменты деревянного перекрытия, перемещенные землеройными животными. На дне находился костяк взрослого человека. Погребенный покоился вытянуто на спине, руки вдоль тела. Головой был ориентирован на север с отклонением к С3. Справа от погребенного лежал железный меч. Тип меча - без перекрестья со штыревидным насадом для ручки. В районе ручки находился халцедоновый диск диаметром 35 мм и несколько фрагментов железных пластин подквадратной формы. Вероятно, рукоять меча была деревянной, а железные пластины были накладками на рукоять. Длина меча in situ без рукояти составляла 90 см. Меч находился в деревянных ножнах, окрашенных в красно-оранжевый цвет.

В районе левого локтевого сустава - сильно корродированные железные предметы (возможно детали Узды). У левой локтевой кости - уздечный набор. Он включал в себя два бронзовых кольца диаметром 4,5 cм с бронзовыми зажимами для крепления ремней, две бронзовых лавролистных пластинки-накладки размерами $6,5 \times 1,8$ см. Рядом находилось скопление полушаровидных бляшек диаметром 17 мм. Некоторые бляшки были прикреплены к кожаной ленте шириной 13 мм. Прикрепление осуществлялось посредством бронзовых скобочек, припаянных к внутренней поверхности бляшек. Контекст находок заставляет предположить, что бляшки служили украшением ремней 


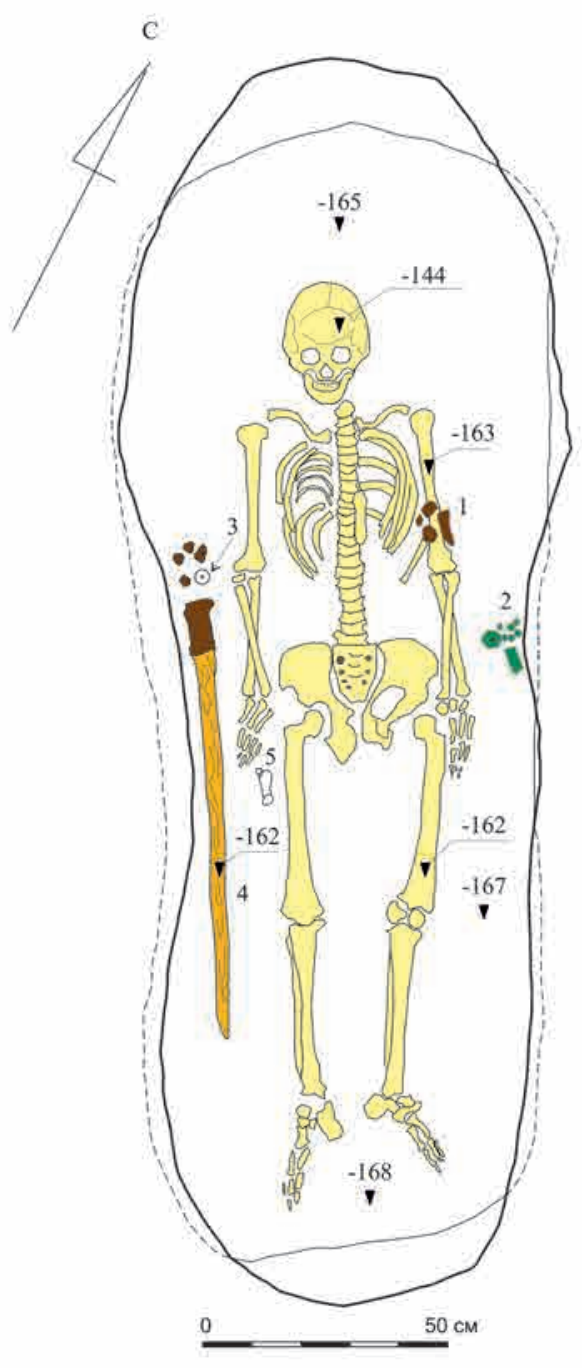

Рис. 1. Мог. Акбулак II, объект № 15 (склепообразное «святилище»»), п. 1. 1 - фрагменты железных предметов;

2 - бронзовый уздечный набор;

3 - навершие меча; 4-железный меч в деревянных ножнах; 5 - бронзовая фибула

Fig. 1. Burial ground Akbulak II, object no. 15 (crypt-shaped "sanctuary"), burial. 1. 1 -fragments of iron objects; 2 -bronze bridle set; 3 - the pommel of the sword;

4 -iron sword in wooden sheath; 5 - bronze brooch

узды. У ладони правой руки находилась бронзовая фибула (рис. 2). Тип фибулы - лучковая с пластинчатым приемником, без орнамента.
Культурно-хронологическая атрибуция. Погребальный обряд (узкая яма, положение погребенного вытянуто на спине с ориентировкой на север), инвентарь (меч без перекрестья с халцедоновым навершием, фибула, уздечный набор) свидетельствует о принадлежности данного погребения к гунно-сарматской культуре [Боталов, 2009, с. 171-199]. Данное погребение входит в круг гунно-сарматских комплексов Западного Казахстана [Боталов, Гуцалов, 2000, с. 65-121]. Наиболее полные аналогии находятся в мог. Целинный I, курган 6 (положение погребенного головой на север с отклонением к С3, меч без перекрестья с халцедоновым навершием, в ножнах красного цвета [Боталов, Гуцалов, 2000, с. 99-101, рис. 33]. И в том же могильнике в сооружении 13 (это также склепообразное «святилище», погребение находится в ЮЗ части, такой же тип меча) [Боталов, Гуцалов, 2000, с. 90, рис. $30,1-6$; с. 102].

Хронологическую позицию дают следующие предметы. Лучковая фибула со слегка прогнутой узкой спинкой, сплошным пластинчатым приемником и удила с бронзовыми зажимами на кольцах позволяют да-

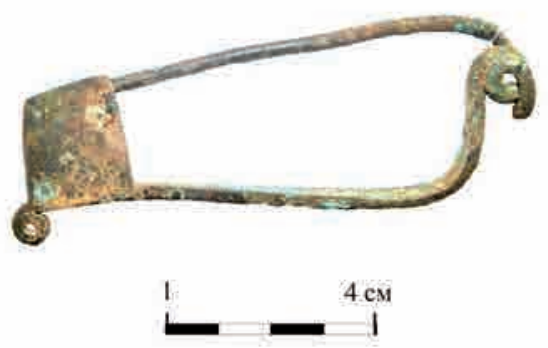

Рис. 2. Бронзовая фибула из погребения, мог. Акбулак II, объект № 15. Фото А.А. Бисембаева

Fig. 2. Bronze brooch from burial, burial ground. Akbulak II, object no. 15. Photo by Bisembayev A. 


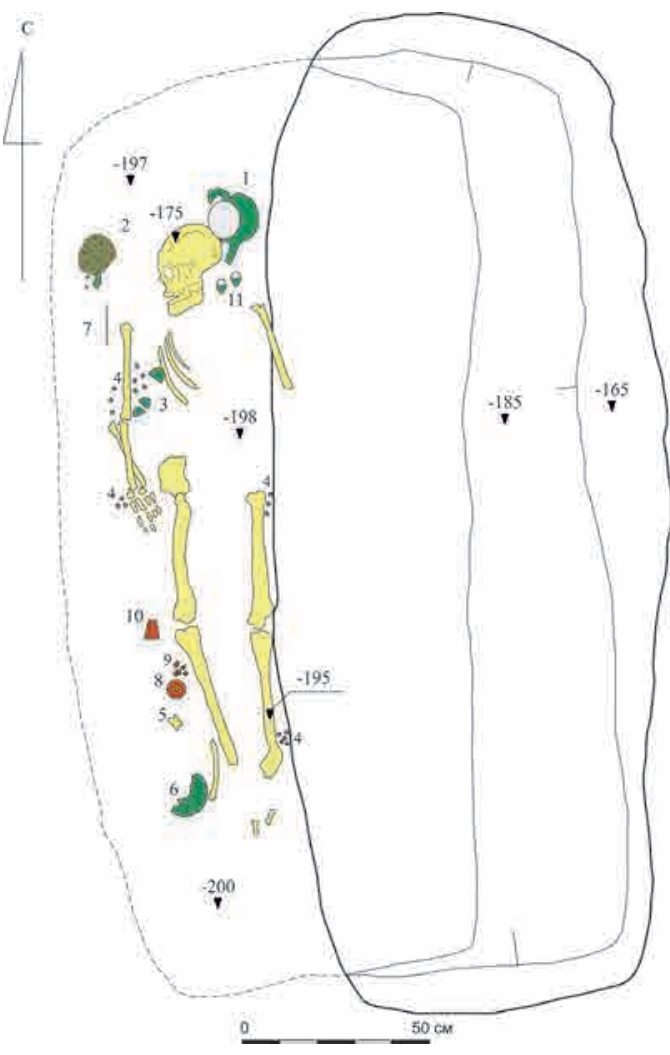

Рис. 3. Мог. Акбулак III, объект № 27 (гантелевидный курган), погребение 1. 1 - бронзовый сосуд; 2 - остатки кожи и скопление бронзовых бляшек;

3 - бронзовые колокольчики;

4 - скопления каменных бусин; 5 - альчик; 6- фрагментьи бронзового зеркала; 7 - бронзовая игла; 8 - округлое керамическое пряслице; 9 - фрагменты железа; 10 - коническое керамическое пряслище; 11 - калачиковидные серьги

Fig. 3. The burial ground. Akbulak III, object no. 27 (dumbbell-shaped mound), burial 1. 1 - a bronze vessel; 2 - remains of skin and accumulation of bronze plaques;

3 - bronze bells; 4 - clusters of stone beads; 5 -alchik; 6 -fragments of a bronze mirror; 7 -bronze needle; 8 -rounded ceramic spindle; 9 - iron fragments;

10 - conical ceramic spindle;

11 - "kalachikovidnye" earrings

тировать это погребение второй половиной II-III вв. (ранний этап по С.Г. Боталову) [Боталов, Гуцалов, 2000, c. 199].
В объекте 27 (гантелевидный курган) могильника Акбулак III выявлено погребение 1 в яме с подбоем (рис. 3). Входная яма подпрямоугольной формы. Размеры 2,65×0,8 м. Ориентирована по линии С-Ю. Стенки относительно ровные, вертикально спускаются ко дну. Вдоль восточной стенки располагается ступенька, шириной $0,3-0,5$ м и высотой 0,5 м, плавно спускающаяся ко дну. В западной стенке располагался подбой, длиной 2,45 м и шириной 0,6 м от западного края входной ямы. Высота подбоя от дна составляла 90 см. На дне находился костяк взрослого человека. Сохранность костей плохая. Поза - вытянуто на спине, руки вдоль тела, головой на север. Череп повернут лицевой частью на запад, имеет следы искусственной деформации.

У теменной части черепа находился бронзовый сосуд с носикомсливом, зооморфной ручкой и кольцевым поддоном (рис. 4). Ручка в сечении округлая, диаметром 8 мм, выполнена в виде фигурки животного. Ноги животного служат основанием ручки, исполнены схематично, отдельные детали не выделены. Животное имеет короткий хвост, круглые выпуклые глаза, вытянутую морду и небольшой выступ на голове, скорее всего рога. Таким образом, ручка изображает, скорее всего, барана или другое животное из семейства парнокопытных. Высота сосуда 15 см, диаметр устья - 11,5 см, диаметр дна - 8 см, высота зооморфной ручки -10 см.

В районе черепа выявлены две бронзовых калачиковидных серьги, полых внутри со стеклянными вставками. В районе стоп - фрагменты разбитого плоского зеркала. Рядом - альчик и керамическое пряслице грибовидной формы. В районе кисти правой руки еаходилось скопление 


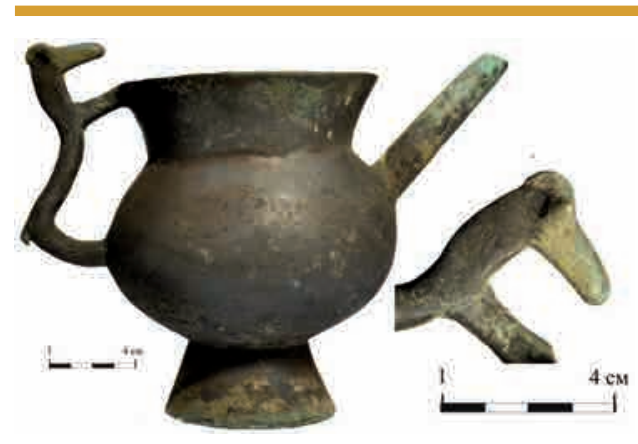

Рис. 4. Бронзовый сосуд из погребения 1 , мог. Акбулак III, объект № 27. Фото А.А. Бисембаева

Fig. 4. Bronze vessel from grave 1, could. Akbulak III, object no. 27. Photo by Bisembayev A.

каменных бусин. У правой плечевой кости - бронзовая игла $(1,5 \times 110$ мм $)$. В районе локтевого сустава правой руки - три бронзовых колокольчика и скопление каменных бусин. Там же зафиксированы две сердоликовых 14-ти-гранных бусины с продетыми в них бронзовыми проволочками. В районе правого коленного сустава пряслице конической формы.

Культурно-хронологическая атрибуция. Погребение в узкой яме с подбоем в западной стенке, северная ориентировка покойного свидетельствует о гунно-сарматской принадлежности погребения [Боталов, 2009, с. 171-199]. Причем инвентарь позволяют предположить женский пол костяка. Погребение с подбоем в западной стенке - характерная черта женских гунно-сарматских захоронений [Боталов, 2009, с. 178]. Аналогичные сердоликовые 14-ти-гранные бусины с подвесками в виде проволочек встречены в кургане 71 могильника Целинный I [Боталов, Гуцалов, 2000, с. 115-117, рис. 37, 9-14]. Датируют комплекс калачиковидные серьги со вставками (IV-V вв.) и 14-ти-гранные бусы с продетыми в них спиральными проволочками (III-V вв.) [Бота- лов, 2009, с. 204]. Точных аналогов бронзовому сосуду пока не найдено. В целом, можно датировать этот комплекс III-IV вв. (поздний этап по С.Г. Боталову).

Другие значимые находки были сделаны в результате доследования разрушенного погребения в песчаном карьере на окраине г. Актобе. В июне 2018 г. в Центр исследования, реставрации и охраны историко-культурного наследия Актюбинской области поступила информация, что в карьере на северной окраине г. Актобе при добыче песка было разрушено захоронение, содержащее золотые вещи. Сотрудниками Института археологии им. А.Х. Маргулана, «Центра... » и Актюбинского историко-краеведческого музея оперативно было проведено доследование погребения.

Погребение располагалось на северной окраине г. Актобе, в песчаном карьере в 2,5 км к ЮВ от моста через р. Илек на северном участке объездной автотрассы. При обследовании на местности было выяснено, что погребение находилось на высоте 3,2 м от дна карьера и на глубине 3,5 м от дневной поверхности. При добыче песка ковшом погрузчика кости и вещи были «вынуты» практически полностью и находились в куче песка на дне карьера. От ямы фактически сохранилась только западная стенка и юго-западный угол. После обнаружения костей работы были остановлены.

Опрос оператора погрузчика показал, что череп вывалился с северной стороны погребения, а кости ног - с южной, из чего можно заключить, что ориентировка погребенного была северной. Каких-либо надмогильных конструкций не было.

Далее с помощью сита было выполнено просеивание грунта и сбор находок. Также была проведена 
зачистка стенки карьера и выявлены остатки могильной ямы. Ситуация осложнялась песчаным грунтом, который постоянно осыпался. Несмотря на это, in situ в южной части ямы был выявлен череп лошади, а в северной - небольшая часть седла (?), не разрушенная техникой. Собранные находки типологически можно разделить на несколько категорий (рис. 5):

- мелкие полушарные бляшки с пуансонным орнаментом по краю;

- крупные полушарные бляшки. В центре имеют выпуклость, которая по краю также окружена выпуклостями, что создает цветочный орнамент;
- халцедоновое навершие меча;

- накладка на навершие меча, обтянутая золотой фольгой, украшенная перегородчатой эмалью;

- серебряная рамочная поясная пряжка с двумя скобками для крепления к ремню;

- бронзовая рамочная поясная (?) пряжка;

- бронзовая круглая рамочная пряжка (2 экз.);

- фрагменты золотой фольги. Общее количество фрагментов - более 100 , вероятно они были частью обкладки какого-то крупного предмета (седла?). Украшены мелким пу-

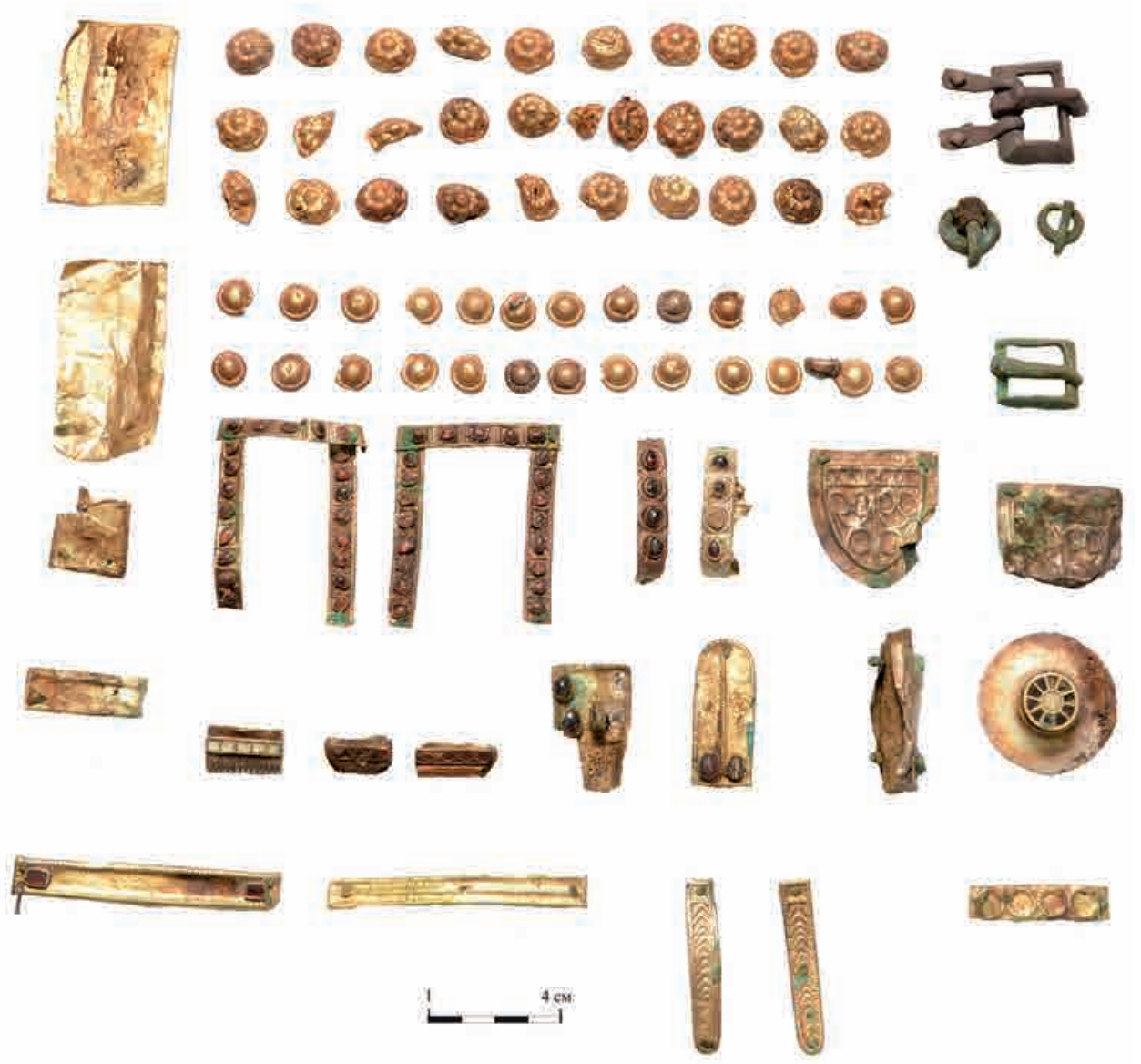

Рис. 5. Предметы из разрушенного погребения у г. Актобе. Фото А.А. Бисембаева

Fig. 5. Artifacts from the destroyed burial near Aktobe. Photo by Bisembayev A. 
ансонными орнаментом в виде треугольников.

- «П»-образные бронзовые накладки с позолотой и вставками из драгоценных камней (2 экз.);

- пластины прямоугольные со вставками из драгоценных камней (2 экз.);

- лавролистные золотые накладки с орнаментом в виде уголков (2 экз.);

- золотые накладки в виде геральдического щита с орнаментом в виде кругов внутри (2 экз.).

\section{Аналогии и культурно-} хронологическая атрибуция. «П»образные накладки, обтянутые золотой фольгой со вставками из драгоценных камней, находят практически полные аналогии в могиле VIII у с. Новогригорьевка [Засецкая, 1994, c. 201 , табл. $5,13,1]$. Халцедоновое навершие с круглой накладкой, покрытой золотой фольгой, с цветной перегородчатой эмалью имеет аналогию в могиле IX у с. Новогригорьевка [Засецкая, 1975, табл. VIII; 1994, с. 199, табл. 3, 8]. В последнем случае навершие выполнено из янтаря. Мелкий пуансонный орнамент в виде треугольников широко встречается на различных золотых предметах гуннского времени [Засецкая, 1975, табл. I, II, V, VII, VIII]. В целом данные вещи изготовлены в гуннском полихромном стиле [Засецкая, 1994, c. 68-75]. Таким образом, в песчаном карьере близ г. Актобе было исследовано элитное захоронение гуннского времени. Предварительно оно может быть датировано III-IV вв.

Заключение. Начатые в начале текущего столетия планомерные разведки на территории соседней Западно-Казахстанской области, в ее восточных, примыкающих к Актю- бинской, районах, а так же первые раскопки в 1990-2000-х гг., показали перспективность поиска памятников начала нашей эры на границе зоны сухой степи и полупустыни, их многочисленность, высокую вариативность наземных сооружений, и соответственно, значительную информативность для такого сложного и пока слабоосвещенного периода, как II-IV вв. [Боталов, Бисембаев, 2002, с. 108 116]. Исследование прямоугольных объектов, с возвышающимися курганообразными сооружениями у входа, в могильнике Сарытау (Хромтауский p-н, Актюбинская обл.), сначала в 1992 г., а затем в 2007 г., позволило получить интересные материалы по системе постройки подобных сооружений, а также были получены бронзовые и железные колокольчики, ювелирные изделия, четко отражающие культурно-хронологическую принадлежность исследованных комплексов [Бисембаев, Дуйсенгали, 2008, с. 99$101 ; 2009$, с. 28-34].

В результате планомерных и целенаправленных исследований, а также в результате случайных находок в Западном Казахстане пласт памятников гуннского времени пополнился новыми важными материалами. Изученные памятники показали значимость изучения территории Западного Казахстана для выяснения вопросов культурогенеза эпохи Великого переселения народов. Были исследованы различные типы объектов (простые курганы, гантелевидный курган, склепообразное «святилище»). Получена представительная коллекция артефактов по вооружению, украшениям, конскому снаряжению и бытовым предметам. В целом исследованные комплексы укладываются в период второй половины II в. н.э. - IV в. н.э. 


\section{ЛИТЕРАТУРА}

1. Бисембаев А.А., Дуйсенгали М.Н. Новые материалы гуннского времени с территории Актюбинской области // УАВ. 2008. Вып. 8. С. 99-101.

2. Бисембаев А.А., Дуйсенгали М.Н. К вопросу о гуннских погребальных памятниках в Западном Казахстане // Известия НАН РК. Сер. обществ. наук. 2009. № 1. C. 28-34.

3. Боталов С.Г. Гунны и тюрки (историко-археологическая реконструкция). Челябинск: ООО ЦИКР «Рифей», 2009. 706 с.

4. Боталов С.Г., Бисембаев А.А. Новые материалы по культуре гуннов Западного Казахстана // Вопросы истории и археологии Западного Казахстана: сб. научн. ст. Уральск, 2002. Вып. 1. С. 108-116.

5. Боталов С.Г., Гуиалов С.Ю. Гунно-сарматы Урало-Казахстанских степей. Челябинск: Рифей, 2000. 266 с.

6. Дуйсенгали М.Н., Мамедов А.М., Баиров Н.М. Предварительные итоги исследования погребально-поминальных комплексов поздней древности бассейна р. Уил // Маргулановские чтения-2018. Духовная модернизация и археологическое наследие: сб. матер. Междунар. научн.-практич. конф. Алматы-Актобе, 2018. С. 237-241.

7. Засеикая И.П. Золотые украшения гуннской эпохи. Л.: Аврора, 1975. 80 с.

8. Засеикая И.П. Культура кочевников южнорусских степей в гуннскую эпоху (конец IV-V вв.). СПб.: Эллипс Лтд, 1994. 224 с.

\section{Сведения об авторах:}

Бисембаев Арман Ауганович - кандидат исторических наук, старший научный сотрудник, Институт археологии им. А.Х. Маргулана (г. Алматы, Казахстан), представитель Института в Западном Казахстане; abissembaev@mail.ru

Хаванский Алексей Иванович - кандидат исторических наук, старший научный сотрудник, Институт археологии им. А.Х. Маргулана (г. Алматы, Казахстан); Arkaim01@yandex.ru

Дуйсенгали Мейрам Нурланович - и.о. директора Актюбинского областного историко-краеведческого музея (г. Актобе, Казахстан); duisenglimeiram@mail.ru

Мамедов Аслан Маликович - директор Центра исследования, реставрации и охраны историко-культурного наследия (г. Актобе, Казахстан); mamedovaslan@mail.ru

Баиров Нурсултан Майлибаевич - научный сотрудник отдела «Археология и этнография», Актюбинский областной историко-краеведческий музей (г. Актобе Казахстан); nmbairov91@mail.ru

Амелин Виктор Алексеевич - научный сотрудник отдела «Археология и этнография», Актюбинский областной историко-краеведческий музей (г. Актобе, Казахстан); vityara2706@mail.ru

\section{8 ЖЫЛҒЫ АҚТӨБЕ ОБЛЫСЫНДАҒЫ ҒҰН КЕЗЕНІНІН ЕСКЕРТКІШТЕРІН ЗЕРТТЕУ \\ (алдын-ала есеп)}

\section{А.А. Бисембаев, А.И. Хаванский, М.Н. Дүйсенғали, А.М. Мамедов, Н.М. Баиров, В.А. Амелин}

Мақалада Қазақстан ғұн кезеңінің ескерткіштеріне (Ойыл ауданы Ақтөбе облысы) жүргізілген қазба жұмыстары, сондай-ақ Ақтөбе қаласындағы қираған қабірді зерттеудің нәтижелері баяндалған. Ақбұлақ II қорымындағы № 15 нысанада (сағана тәрізді «ғибадатхана») айқышсыз темір семсерлі, қола жүген жиынтығы бар және фибулалы жауынгердің қабірі зерттелді. Ақбұлақ III қорымындағы 27 нысанда 
(гантелге ұқсас қорған) шұңқырға жүген жабдықтары көмілген 1 қабір анықталды. Қабірге шүмегі, тұғыры және зооморфтық тұтқасы бар қола ыдыс қойылған. Ақтөбе қаласындағы қираған қабірден ғұндық полихромдық нақышта орындалған алтын заттар, белбеу айылбасы табылды. Жалпы алғанда қару-жарық, әшекейлер, ат әбзелдері мен тұрмыстық бұйымдар бойынша артефактілердің қомақты жиынтығы алынды. Зерттелген кешендер II ғ. екінші жартысы - IV ғ. кезеңге жатқызылады.

Түйін сөздер: археология, Батыс Қазақстан, ғұндар, жерлеу рәсімі, ғұн полихромды стилі

\section{RESEARCH OF MONUMENTS OF THE HUN TIME IN THE AKTOBE REGION IN 2018 (preliminary report)}

\section{A.A. Bisembaev, A.I. Khavansky, M.N. Duisengali, A.M. Mamedov, N.M. Bairov, V.A. Amelin}

The article describes the results of the excavation of monuments of the Hun time in the Wil district of the Aktobe, as well as the results of the research of the destroyed burial near the city of Aktobe. In object no. 15 (the crypt-like "sanctuary") of Akbulak II burial ground, the burial of a warrior with an iron sword without crosshairs, a bronze bridle set and a fibula was investigated. In object 27 (the dumbbell burial mound) of Akbulak III burial ground, burial 1 in a pit with a fault was revealed. The burial contained the remains of the buried with many ornaments. Also in the burial was a bronze vessel with a spout, pallet and zoomorphic handle. In the ruined burial near Aktobe gold objects were found in the Hunnish polychrome style (pads with inserts of precious stones, plaques with ornament, chalcedony pommel of a sword with a gold overlay with cloisonne enamel), silver belt buckle. In general, a representative collection of artifacts for armament, decorations, horse equipment and household items has been obtained. On the whole, the complexes studied are within the period of the second half of the 2nd century AD - IV AD.

Keywords: archaeology, Western Kazakhstan, Huns, funeral rite, Hun polychrome style.

\section{REFERENCES}

1. Bissembaev, A. A., Duisengali, M. N. 2008. In Ufimskii arheologicheskii vestnik (Ufa Archaeological Bulletin), 8, 99-101 (in Russian).

2. Bissembaev, A. A., Duisengali, M. N. 2009. In Izvestiya NAN RK (News of the National Academy of Sciences of the Republic of Kazakhstan), 1, 28-34 (in Russian).

3. Botalov, S. G. 2009. Gunny i tyurki (Huns and Turks). Chelyabinsk: "Rifey" Publ. (in Russian).

4. Botalov, S. G., Bissembaev, A. A. 2002. In Voprosy istorii i arheologii Zapadnogo Kazahstana (Questions of history and archeology of Western Kazakhstan), 1, 108116 (in Russian).

5. Botalov, S. G., Gutsalov, S. Yu. 2000. Gunno-sarmaty Uralo-Kazakhstanskih stepey. (Gunno-Sarmatians of the Ural-Kazakhstan steppe). Chelyabinsk: "Rifey" Publ. (in Russian).

6. Duysengali, M. N., Mamedov, A. M., Bairov, N. M. In Margulanovskie chteniya2018 (Margulan readings-2018). Almaty - Aktobe, 237-241 (in Russian).

7. Zasetskaya, I. P. 1975. Zolotyye ukrasheniya gunnskoy epohi (Golden jewelry of the Hun era). Leningrad: "Avrora" Publ. (in Russian).

8. Zasetskaya, I. P. 1994. Kul'tura kochevnikov yuzhnorusskikh stepey v gunnskuyu epohu (konets IV-Vvv.) (The culture of the nomads of the South Russian steppes in the Hun era (end of 4-5 in $A D)$ ). Saint Petersburg: "Ellips" Publ. (in Russian). 


\section{About the Authors:}

Bisembaev Arman A. Candidate of Historical Sciences, Senior Researcher, A.Kh. Margulan Archeology Institute, Almaty, Kazakhstan, representative of the A.Kh. Margulan Archeology Institute in Western Kazakhstan; abissembaev@mail.ru

Khavansky Alexey I. Candidate of Historical Sciences, Senior Researcher, A.Kh. Margulan Archeology Institute, Almaty, Kazakhstan; Arkaim01@yandex.ru

Duisengali Meiram N. Acting director, Aktobe regional museum of local lore, Aktobe, Kazakhstan; duisenglimeiram@mail.ru

Mamedov Aslan M. Director of the Center for Research, Restoration and Protection of Historical and Cultural Heritage, Aktobe, Kazakhstan; mamedovaslan@mail.ru

Bairov Nursultan M. Research associate of the department "Archeology and Ethnography", Aktobe regional museum of local lore, Aktobe, Kazakhstan; nmbairov91@mail.ru

Amelin Viktor A. Research associate of the department "Archeology and Ethnography", Aktobe regional museum of local lore, Aktobe, Kazakhstan; vityara2706@mail.ru

\footnotetext{
Мүдделер қақтығысы туралы ақпаратты ашу. Авторлар мүдделер қақтығысының жоқтығын мәлімдейді. / Раскрытие информации о конфликте интересов. Авторы заявляют об отсутствии конфликта интересов. / Disclosure of conflict of interest information. The authors claims no conflict of interest.

Мақала туралы ақпарат / Информация о статье / Information about the article.

Редакцияға түсті / Поступила в редакцию / Entered the editorial office: 27.08.2018.

Рецензенттер мақұлдаған / Одобрено рецензентами / Approved by reviewers: 03.09.2018.

Жариялауға қабылданды / Принята к публикации / Accepted for publication: 10.09.2018.
} 